NBER WORKING PAPER SERIES

BUSINESS AND FINANCIAL METHOD PATENTS, INNOVATION, AND POLICY

Bronwyn H. Hall

Working Paper 14868

http://www.nber.org/papers/w14868

\author{
NATIONAL BUREAU OF ECONOMIC RESEARCH \\ 1050 Massachusetts Avenue \\ Cambridge, MA 02138 \\ April 2009
}

This is a substantially revised and expanded version of a paper prepared for the Atlanta Federal Reserve Bank Conference on Business Method Patents, Sea Island, Georgia, April 3-5, 2003 and the EPIP Network Conference on New Challenges to the Patent System, Munich Germany, April 24-25, 2003. Comments from participants in those conferences are gratefully acknowledged. The views expressed herein are those of the author(s) and do not necessarily reflect the views of the National Bureau of Economic Research.

NBER working papers are circulated for discussion and comment purposes. They have not been peerreviewed or been subject to the review by the NBER Board of Directors that accompanies official NBER publications.

(C) 2009 by Bronwyn H. Hall. All rights reserved. Short sections of text, not to exceed two paragraphs, may be quoted without explicit permission provided that full credit, including $\odot$ notice, is given to the source. 
Business and Financial Method Patents, Innovation, and Policy

Bronwyn H. Hall

NBER Working Paper No. 14868

April 2009

JEL No. G28,K2,L86,O34

\begin{abstract}
$\underline{\text { ABSTRACT }}$
Two court decisions in the 1990s are widely viewed as having opened the door to a flood of business method and financial patents at the US Patent and Trademark Office, and to have also impacted other patent offices around the world. A number of scholars, both legal and economic, have critiqued both the quality of these patents and the decisions themselves. This paper reviews the history of business method and financial patents briefly and then explores what economists know about the relationship between the patent system and innovation, in order to draw some tentative conclusions about their likely impact. It concludes by finding some consensus in the literature about the problems associated with this particular expansion of patentable subject matter, highlighting the remaining areas of disagreement, and reviewing the various policy recommendations.
\end{abstract}

Bronwyn H. Hall

Dept. of Economics

549 Evans Hall

UC Berkeley

Berkeley, CA 94720-3880

and NBER

bhhall@nber.org 


\section{Business and Financial Method Patents, Innovation, and Policy}

\section{Bronwyn H. Hall'}

\section{Introduction}

The explosion in business method patent applications and grants that occurred in 1999-2001 has abated somewhat, and the legal landscape has changed as a result of several court decisions. However, the many policy questions raised by the response of the financial, e-commerce, and software industries to the well-known State Street Bank decision on the patentability of business methods remain. Many scholars, both legal and economic, wrote on this topic shortly after the decision and the accompanying increase in patents in this technological area. ${ }^{2}$ Although much of this literature provides a fairly thorough analysis of individual cases and what they signify, there was relatively little literature on the impact of business method patents based on a more broad-based or empirical approach. Notable exceptions to this are a series of studies of financial method patents by Lerner (2001, 2006a,b) and some studies of business method patents by Allison and Tiller (2003), Hunt (2008), Wagner (2008), and Hall, Thoma, and Torrisi (2009) .

The current paper reviews the evolution of patenting in this area and reviews some of the literature on patents more broadly in an attempt to infer the implications of this literature for business method patents. The focus is on two issues: the role of patents in encouraging innovation and the consequences of low patent quality for the performance of the system. I begin by reviewing the facts about business method patents briefly, and then survey what economists know about the general relationship between patent systems and innovation, in order to draw some implications for the likely impact of business method patents on innovation in industry. A discussion of the patent quality issue is followed by a summary of the policy recommendations made by those who have followed the evolution of legal standards as both software and business methods have become acceptable subject matter.

${ }^{1}$ University of California at Berkeley, University of Maastricht, and NBER. This is a substantially revised and expanded version of a paper prepared for the Atlanta Federal Reserve Bank Conference on Business Method Patents, Sea Island, Georgia, April 3-5, 2003 and the EPIP Network Conference on New Challenges to the Patent System, Munich Germany, April 24-25, 2003. Comments from participants in those conferences are gratefully acknowledged.

${ }^{2}$ See, for example, Bakels and Hugenholtz (2002), Bessen and Maskin (1997), Blind et al (2001), Cockburn (2001), Cohen and Lemley (2001), Davis (2002a,b), Dreyfuss (2000), Hart et al (1999), Hunt (2001b), Kasdan (1999), and Lerner (2001). 
Most economists view the patent system as a necessary evil: with a patent grant we trade off short term exclusive (monopoly) rights to the use of an invention in return for two things: 1) an incentive to create the innovation; and 2) early publication of information about the innovation and its enablement. The argument is that without the patent system, fewer innovations would be produced, and those that were produced would be kept secret as much as possible to protect the returns from misappropriation. Mazzoleni and Nelson (1998) expand on this analysis and provide two further related arguments for the existence of a patent system: it serves as an inducement for the needed investments to develop and commercialize inventions, and it enables the "orderly exploration of the broad prospects" opened up by particularly novel inventions. In considering the economic impacts of the implicit subject matter extension implied by the increased use of patents to protect business methods, the tradeoff between these benefits and the welfare cost of the grant of a monopoly right are at least as important as they are in any other technological arena.

As our understanding of the uses and abuses of the patent system has grown, other benefits (to competition) and costs (to innovation) have emerged as important. Table 1 summarizes the basic dilemna: the patent system can generate both benefits and costs, for both innovation and competition. Economic analysis says first that competition may suffer when we grant a monopoly right to the inventor of a business method but it will benefit if this right facilitates entry into the industry by new and innovative firms, and allows the development of markets for technology. Second, innovation will benefit from the incentive created by a patent but may suffer if patents discourage or raise the cost of combining and recombining of inventions to make new products and processes. Thus the relationship between patents, competition, and innovation is guaranteed to be a complex one, and one that may vary over time and across industries.

\section{Background and history}

There is no precise definition of a business method patents, and in reading the literature it becomes clear that many scholars make little distinction between business method patents, internet patents, and software patents more broadly, at least when making policy recommendations. This is inevitable in the present day, because many business method patents are in fact patents on the transfer of a known business method to a software and/or web-based implementation, so the distinction is hard to maintain. In addition, almost all patent offices draw some kind of line between a method of doing something that does not have a "technical effect" (in the case of the EPO) or is not "tied to a particular machine or apparatus" or does not transform one thing to another (the USPTO after the in re Bilski decision) and a patentable business method. This line is inevitably fuzzy and has moved over time. 
For the purpose of examination, the USPTO defines a business method patent fairly narrowly, as a patent classified in US patent class 705, defined as "data processing: financial, business practice, management, or cost/price determination." Such patents are on methods used for a variety of purposes in business such as the following: ${ }^{3}$

- Financial - credit and loan processing, point of sale systems, billing, funds transfer, banking clearinghouses, tax processing, and investment planning

- Financial instruments and techniques - derivatives, valuation, index-linking

- Optimization - scheduling and resource allocation

- Marketing - advertising management, catalog systems, incentive programs, and coupon redemption

- Information acquisition, human resource management, accounting, and inventory monitoring

- e-commerce tools and infrastructure - user interface arrangements, auctions, electronic shopping carts, transactions, and affiliate programs

- Voting systems, games, gambling, education and training

Examples of business method patents are the well-known one-click patents assigned to Amazon.com, the Dutch auction patent of Priceline.com, and of course the Signature Financial patent on a system of managing multiple mutual funds in a single account that was the subject of the State Street decision described below.

\subsection{A brief legal history}

Statutory subject matter for patenting is defined by section $\S 101$ of the U.S. code as any new and useful machine, article, process, or composition of matter. Precedents set during the long legal history of patentability have interpreted this definition to exclude laws of nature, natural phenomena, and abstract ideas. It is the shades of difference in meaning between the definition of a "new and useful" item and an "abstract idea" that is the source of the debate surrounding business methods as a suitable subject matter for patentability and the difficulty in clearly delineating that subject matter. Clearly it is possible to imagine an abstract idea that is new and useful, so the exclusion rests on the inclusiveness or exclusiveness of the words "machine, article, process, or composition of matter."

In 1998, the US Court of Appeals of the Federal Circuit (CAFC) issued a decision that is widely viewed as having opened the door to widespread business method patenting, especially financial methods, in the State Street Bank and Trust v Signature Financial Corporation case. ${ }^{4}$ The Signature patent at issue

\footnotetext{
${ }^{3}$ See the USPTO White Paper (1999) for further description and categorization of these patents.

${ }^{4}$ State Street Bank and Trust Co., Inc. v. Signature Financial Group, Inc., 149 F.3d 1368 (Fed. Cir. 1998).
} 
was a "pure" number-crunching software program application, which implemented a method of valuing mutual funds. ${ }^{5}$ The Federal Circuit Court decision, authored by Judge Rich, stated clearly that section $\S 101$ of the US patent law is unambiguous - "any" means ALL, and it was improper to read limitation into 101 not intended by Congress. Therefore, mathematical algorithms are non-statutory only when "disembodied" and thus lacking a useful application. The court went on to make sure that the decision was precedent-setting by stating that with regard to the business method exception, "We take this opportunity to lay this ill-conceived exception to rest."

In a subsequent case, AT\&T v Excel, where the patent at issue contained a method claim about adding a data field to a record for use in a billing system, the Federal Circuit confirmed the State Street decision, saying that a physical transformation was not required for a method claim to be statutory and that mathematical algorithms were patentable if "embodied" in an invention. That is, the State Street decision applies to methods as well as to machines.

Two recent cases have changed the landscape somewhat in the business patent area, making it somewhat more difficult to obtain such a patent and also more difficult to enforce the patent, once obtained. In a high profile case that ended in the Supreme Court, MercExchange sued e-Bay for infringement of a series of patents on computerized marketplaces. The decision in this case is widely viewed as shifting the bargaining point between a non-working patent holder and a potential infringer. In May 2006, the Court ruled that a four factor test must be used to decide whether to issue a permanent injunction in a patent case. ${ }^{6}$ Before an injunction is issued by the court, a patent owner must show (1) it has suffered irreparable injury; (2) monetary damages are inadequate compensation; (3) a remedy in equity is warranted; and (4) the public interest would not be disserved. Applying this test should make it more difficult for patent holders that do not offer a product embodying the invention in question to obtain injunctions against those who do.

The second important recent case is in re Bilski, which was decided by the Court of Appeals of the Federal Circuit in October 2008. ${ }^{7}$ This ruling addressed which technologies are eligible for patent protection, reinstating a test familiar from decisions in the 1970s and early 1980s, and to some extent stepping back from the State Street test of patentability (that the invention need only have a "concrete,

${ }^{5}$ The description of the patent in the court's decision was that it was "generally directed to a data processing system (the system) for implementing an investment structure which was developed for use in Signature's business as an administrator and accounting agent for mutual funds. In essence, the system, identified by the proprietary name Hub and Spoke, facilitates a structure whereby mutual funds (Spokes) pool their assets in an investment portfolio (Hub) organized as a partnership. This investment configuration provides the administrator of a mutual fund with the advantageous combination of economies of scale in administering investments coupled with the tax advantages of a partnership."

\footnotetext{
${ }^{6}$ http://www.supremecourtus.gov/opinions/05pdf/05-130.pdf

${ }^{7}$ http://www.cafc.uscourts.gov/opinions/07-1130.pdf
} 
useful, and tangible result"). The new test for patentable software says that a process will be patentable if "(1) it is tied to a particular machine or apparatus, or (2) it transforms a particular article into a different state or thing." The Court expressed concern that a patent should not "pre-empt substantially all uses of a fundamental principle." Besides the implications for algorithmic patents, the decision is also viewed as ruling out medical methods as patentable subject matter.

Thus the set of patents that could be classified as business method or financial method patents will change over time as the subject matter definitions used by the USPTO change, either in response to court rulings, or to other changes, including legislative. At the current time, there are two main patent classes containing these patents: 705 (data processing: financial, business practice, management, or cost/price determination) and 902 (electronic funds transfer). It is of course possible that patents we might view as business method patents are classified elsewhere in the patent system. For example, patent number 5,851,117, which describes a training system for training janitors, is classified as 434, "education and demonstration." and patent number 6,015,947, which describes a method of teaching music, is classified as 84, "music". In this paper, I do not use patents in classes such as these, because the business method share of the class is quite small and it is not feasible to read each patent separately. The main patent classes that contain software and business method patents, broadly defined, are shown in Table 3. Among these classes, only 705 and 902 contain modern business method patents. About half of these are related to financial methods and payment services, and half to other business methods. ${ }^{8}$

Figures 1 (by year of application) and 2 (by year of grant) give an idea of the relative importance of software and business method patents according to various patent class definitions. Under a broad definition of software/business methods, the USPTO is now granting about 10 to 12 thousand patents per year, as opposed to fewer than a thousand per year before 1985. ${ }^{9}$ Pure business method patents (those in class 705) are still a small share of the total, with about a 1000 granted per year, and with a notable decline in grants in 2001 and 2002 probably because of the second review of this class that was instituted by the USPTO. ${ }^{10}$ Figure 3 shows the evolution of class 705 patents: applications grow very slowly until

${ }^{8}$ I define financial and payment service patents as the union of definitions due to Hall (2007) and Lerner (2006): those 705 patents in subclasses $4,14,16-18,21,33,35-45,53-56,64-79$ plus any class 902 patents. See the appendix for a complete list of the subclasses. Although class 902 seems from its description to be a likely repository of many financial services patents, in fact there is only one patent with primary classification in 902 granted by the end of 2006, which is when my data sample ends.

${ }^{9}$ The definition used is the combined definition from Hall and MacGarvie (2007).

${ }^{10}$ In discussion of this paper, Josh Lerner suggested that the decline may be partly due to strategizing on the part of firms to avoid having a potential business method patent classified into 705, so that it would not be scrutinized twice at the USPTO. This seems likely, but there is no way to measure this effect using publicly available data. 
the in re Alappat decision of 1994, which was widely viewed as opening the door to "pure" software patents in the U.S.

As the low numbers of some of the classes indicate, business method patents of some sort have existed for a long time, although not necessarily in large quantities. According to the USPTO (1999), the earliest business method patents were for methods of printing money and detecting counterfeit bills. ${ }^{11} \mathrm{~A}$ patent was issued in 1857 for the idea of including local advertising in a hotel register. Since the mid1990s, the numbers have increased substantially, largely due to the two previously mentioned court decisions and their aftermath, in re Alappat in 1994 and then State Street v. Signature Financial in 1998. Nevertheless, class 705 patents are still on the order of one half of one percent of all patents applied for, whereas software patents are now about 6 per cent of all patents, using the Hall-MacGarvie combined definition (2007). For comparison, Hall et al. (2009) find that financial method patents are only about $0.2 \%$ of patent applications and $0.1 \%$ of patent grants at the EPO during the 1995-2002 period.

The success of the patentholder in the State Street and ATT v Excel cases clearly emboldened others who held patents on internet-based methods of doing business. Table 2 lists some of these patents and the disputes in which they were involved: they include the well-known one-click patent of Amazon, the Priceline name-your-price auction, and the widely critiqued Y2K windowing patent. ${ }^{12}$ The history of SSL public key encryption technology is instructive: the original patent $(4,405,829)$ was granted to MIT in 1983 on an application in 1976 that had been blocked by another 1976 patent issued in 1980 to Cylink, a Stanford University spin-off. As SSL became the dominant technology in the area of secure websites, the IETF managed to persuade RSA Security (the MIT spin-off) to yield some IP to the public standard in the late 1990s. Then in 2001, Leon Stambler sued RSA Security and Verisign over his 1993 patents, which claimed to cover the SSL public key encryption. In 2005, RSA Security and Verisign were found not to have infringed the Stambler patents. Several other disputes of this kind ended in these patents being invalidated, but others led to settlements with undisclosed royalty payments. This illustrates both the complexity of the technology and the complexity of the disputes in the case of a valuable standard.

Because many of the past cases have ended in some kind of settlement with undisclosed terms, so it is difficult to form a precise picture of the licensing royalties involved. It is, however, noteworthy that

\footnotetext{
${ }^{11}$ The first financial patent was granted on March 19, 1799, to Jacob Perkins of Massachusetts for an invention for "Detecting Counterfeit Notes." Patent number X2301 was granted to John Kneass on April 28, 1815 for a "A Mode of Preventing Counterfeiting." The hotel register patent is number 63,889. See USPTO (1999).

12 This author was one of many who was incredulous when this patent, which solves the Y2K 2-digit year problem by redefining the base year, issued. Like some others, she had software (in this case, TSP) on the market using this method a good 15 years before patent 5,806,063 was applied for. The Patent Commissioner ordered a reexamination of this patent in 1999, and a final rejection of all claims was issued on June 10, 2005. After appeal, the rejection was finally affirmed by the USPTO Board of Appeals on March 16, 2009 (!). Among other things, this case illustrates the time and resources that can be consumed even by a dubious patent in this area.
} 
most of the cases concern internet patents rather than "pure" business method patents. Following Lanjouw and Schankerman (2001), this suggests that these are the high value and enforceable patents in this area. The more frivolous business method patents (such as 6,257,248, for cutting hair with scissors in both hands, or the previously mentioned $6,368,227$, for a method of swinging on a swing) are probably unenforceable.

\subsection{Business method patenting outside the US}

According to the TRIPS agreement of the WTO, neither business methods nor software are specifically excludable subject matter for patentability (Diallo 2003). With respect to software, national treatment varies, but in most countries at least some types of software (especially those with a "technical effect" or where they are embodied in hardware) are now patentable. ${ }^{13}$ At the present time, business methods are patentable (with some restrictions) in the United States, Australia, Japan, Singapore, and possibly Korea, but not in Europe including the UK, and Canada. In the UK, for example, the Patent Office introduced special treatment for business method applications in November 2004, due to the increasing number that had little or no chance of being granted (MIP Week 2004). In so doing, the Director cited applications from Fujitsu for optimizing the scheduling of airline crews, and a system for managing a debt-recovering process as being inherently unpatentable. In general UK practice with respect to software patents is viewed by practitioners as more restrictive than that at the EPO (MIP Week 2007).

Several researchers have looked at various types of business method patents applied for or granted at the European Patent Office (EPO). Wagner (2008) examined 1901 EPO applications that had granted US equivalents in class 705, finding that these patents had more claims and a longer pendency than other patents, and were mostly taken out by large US and Japanese electronic and computer firms. About 70 per cent of them are granted (fewer for US applicants) and of those granted, 16 per cent were opposed, a relatively high rate. The most interesting finding was very active opposition (44 per cent of granted patents) in a single technology area dominated by one American (Pitney-Bowes) and three European firms: franking devices. The fact that Pitney-Bowes, by far the largest patentholder, was the opposed and the other three firms the opposers in most cases suggests that these competitors (Societe Secap, Neopost Ltd, and Francotyp-Postalia) feared being locked out of technologies they were already using without having patented them.

Hall, Thoma, and Torrisi (2009) study financial method patents at the EPO, using a variety of definitions to identify them. They find that the majority are held by large established firms in non-

\footnotetext{
${ }^{13}$ See Spindler (2003) for a useful discussion of the current state of play in Europe, and EC (2002) for the draft European directive on software patent policy.
} 
financial sectors, as Lerner (2001) found for the United States and Wagner found for Europe. Decisions on these patent applications take longer and they are more likely to be rejected, suggesting uncertainty over subject matter eligibility along with value to the applicant. As Wagner found for the subset of these patents with US equivalents, they are more likely to be opposed once issued, consistent with the fact that their other value indicators such as citations are also higher than for patents as a whole.

It would be interesting to ask whether the difference in treatment of business method and financial patents at the USPTO and the EPO has made any difference for business method and internet innovation in the two sets of countries. Unfortunately, this particular research has not yet been undertaken, probably because it is still too early for there to be much evidence and also because there are other confounding influences which make the comparison difficult. Thus I turn to the empirical evidence on the effects of having a patent system on innovation in general in the next section of the paper.

\section{Does the patent system increase innovative activity?}

Although almost the holy grail of innovation policy research, this question has proved exceedingly difficult to answer due to the absence of real experiments. As I suggested in the introduction, economic theory does not supply an unambiguous answer to the question, so that it is essential to rely on empirical observations where a patent system has been introduced, eliminated, or changed in major ways. In this section of the paper, I first review the theoretical results briefly and then turn to the empirical evidence on innovation and the patent system.

\subsection{Theoretical results}

The first result from theory is the well-known argument that granting a patent on an innovation will both incent the inventor, raising welfare, and create a temporary monopoly with its attendant deadweight loss. This rather stark result is mitigated somewhat by two observations: the first is that inventors are often motivated by a variety of factors, not all of which are financial. The second is that innovators are often creative in securing returns to their inventions even in the absence of a patent by bringing the innovation to the market speedily and by secrecy. Based on these observations, we might expect the patent system to be an important incentive system when 1) considerable funds are needed to develop an invention, as in the case of pharmaceuticals or complex modern information technology, and 2 ) it is difficult to keep the innovation secret, or imitation is easy.

More recently, a number of theorists beginning with Scotchmer $(1991,1996)$ and Green and Scotchmer (1995) have stressed the negative effects of patenting in industries with cumulative or sequential technology where each innovation builds on the last, as well as the impossibility of getting the incentives right unless there is enough information to enable contracts to be written before the first 
invention. Incentives to develop follow-on innovation in these industries are reduced by the need to pay licensing fees to the earlier inventors. In principle, for industries with very complex technologies, the problem of contracting for many small pieces of technology may be so severe that transactions costs discourage invention altogether (Heller and Eisenberg 1998; Grindley and Teece 1997).

For my purposes here, the work of Bessen and Maskin (2006) and Hunt (2001a) are probably the most directly appropriate. Bessen and Maskin use a model of sequential innovation where each invention builds on the preceding to show that patent protection does not encourage innovation as much as in the static non-sequential setting, and may even discourage it. Hunt modeled sequential innovation along with a variable standard of patentability (non-obviousness) and asked how a patent system is likely to impact innovation in this case. He assumes an environment where the profitability of inventions is continuously eroded by the introduction of new, competing technologies and where the strength of the nonobviousness requirement for obtaining a patent determines the proportion of new discoveries that do not affect the profits earned by older proprietary discoveries. He then analyzes the consequences of lowering the nonobviousness requirement, showing that there are two competing effects: a static effect in which R\&D incentives are increased because more inventions are patentable and a dynamic effect in which incentives are decreased because the profit from any given invention is lower since it will be replaced more quickly.

Two conclusions are drawn from this analysis: 1) there exists a unique standard of nonobviousness that maximizes the rate of innovation in a given industry; and 2) contrary to the conventional wisdom, reductions in the nonobviousness requirement are more likely to encourage innovation in industries that innovate slowly than in industries that innovate rapidly. The implication is that in rapidly innovating industries where each new product builds on others, welfare is more likely to be enhanced by having a high hurdle for obtaining a patent. O'Donoghue (1998) uses a slightly different model of sequential innovation and draws a similar conclusion, that increasing the standard of patentability can increase $R \& D$ as firms go after larger innovations, even though the overall cost of obtaining a patent has risen.

As a general rule, the theoretical work discussed here has abstracted from the frictions introduced by uncertain patent validity, transaction costs such as those needed to negotiate licenses, and the costs of litigation for infringement and validity that arise either because of bargaining breakdown or real uncertainty about the patentability. Yet there is considerable anecdotal (Federal Trade Commission 2003) and some empirical evidence (e.g., Lerner 1995) that these frictions can be an important component of the cost of a patent system, and hence more patents or lower quality patents may be a drag on innovation because they increase transactions costs without increasing innovation incentives. In a recent article, Farrell and Shapiro (2008) consider the problem of uncertain validity and show that when downstream firms compete with themselves or with the upstream firm that holds the patent, social welfare is improved 
by determining the validity of the patent before licensing. As they conclude, weak patents can be surprisingly strong.

The main conclusion from theoretical work in this area is that whether patents are a socially useful way to encourage innovation turns on the characteristics of the innovation process and the complexity of the products which "read on" the patents. For this reason, I now turn to a review of the empirical evidence on the question.

\subsection{Empirical evidence}

Most researchers who have investigated the question of innovation and the patent system empirically have looked at historical eras when there were changes to the system and examined the consequences for subsequent innovative activity. Recently there have been a pair of studies that use mainly $19^{\text {th }}$ century data (when there was substantial variation across countries in patent systems). One uses invention data from World's Fairs and Expositions and one uses patenting itself as the innovation measure.

Moser (2005) finds that inventors in countries without a patent system do not innovate more than inventors in countries with patent systems. However, inventors in countries without patent systems do tend to innovate in areas that are more easily protected with trade secrecy. Lerner (2002) finds that when a country strengthens its patent system, inventors from other countries patent more in that country. However, inventors from the country itself do not appear to invent more - they neither patent more in their own country, nor in Great Britain (which was chosen as a reference country, because it was a very important market in the $19^{\text {th }}$ century and one with a well-functioning patent system that was widely used).

Results using data from the 20th century are harder to find, but survey evidence exists. The first study was probably that by Mansfield (1986), who surveyed 100 U. S. manufacturing firms in the early 1980s, finding that patents were important for innovation only in pharmaceuticals and chemicals, although firms in all sectors reported that they patented more than half of their patentable inventions. This basic result has held up to the present day.

The Carnegie-Mellon and Yale surveys (Cohen et al 2000 and Levin et al 1987) demonstrate fairly clearly that patents are NOT among the important means to appropriate returns to innovation, except perhaps in the pharmaceutical industry. Similar results have been obtained by other researchers for Europe and Japan. Arundel (2001) reports the results of the PACE survey of large European firms, accounting for more than $75 \%$ of the patenting in Europe. In both the United States and Europe, firms rate superior sales and service, lead time, and secrecy as far more important than patents in securing the returns to innovation. Patents are usually reported to be important primarily for blocking and defensive purposes. 
Using a somewhat more complex economic model and the same survey evidence, Arora, Ceccagnoli, and Cohen (2003) find that the patent premium, which they describe as the difference in payoffs to patented and unpatented inventions net of patent application costs, is not positive on average except for the medical instruments sector. Nevertheless, selecting on those inventions that actually are patented, the premium is generally positive and provides an incentive for $\mathrm{R} \& \mathrm{D}$ that is considerable in the health-related industries and still positive in other sectors.

The most positive results are those obtained using time series-cross section data at the country level. Unfortunately such studies are rarely free of the criticism that the relationship between innovative activity and patenting at the country level is largely simultaneously determined and not causal. In a 1997 paper using aggregate data across 60 countries for the 1960-90 period, Park and Ginarte find that the strength of the IP system (an index based on coverage, especially whether pharmaceuticals are covered; membership in international agreements; lack of compulsory licensing and working requirements; strength of enforcement; and duration) is positively associated with $R \& D$ investment in the 30 countries with the highest median incomes (that is, G-7 and other developed countries, mostly in Europe). In the other countries, the relationship is positive but not significant. Unfortunately their estimates are crosssectional and not corrected for the simultaneity (reverse causality) between doing R\&D and having a patent system, which may explain why they are so different from those of Moser and Lerner. Similar results are reported by Kanwar and Evenson (2003), who also did not control for simultaneity.

Using a database of 26 countries whose pharmaceutical patenting laws changed between 1978 to 2002 and propensity score matching techniques, Qian (2007) provides a more nuanced view. There was no evidence that the change itself had an impact on innovative activity, measured as cite-weighted patents, R\&D, or pharmaceutical exports. However, countries with higher levels of education, development, and economic freedom did experience an increase in innovation. That is, there was an interaction effect, but this effect diminished at the highest levels of patent protection, suggesting that an intermediate level was optimal.

Sakakibara and Branstetter (2001) studied the effects of expanding patent scope in Japan in 1988. According to the Japanese firms and patent attorneys that they interviewed, a statutory change that allowed multiple claims per patent (as has always been true in the U.S.) had the effect of increasing patent scope in Japan. They found that this change to the patent system had a very small positive effect on R\&D activity in Japanese firms.

Hall and Ziedonis (2001) looked at a single industry (semiconductors) that doubled its patenting$\mathrm{R} \& \mathrm{D}$ rate after the creation of the CAFC and other changes to patent legislation in 1982. Interview evidence suggested that the increase was due to the fact that inventions in this industry use technology that is covered by hundreds of patents held by a number of firms, and that firms increasingly feared 
litigation and preliminary injunctions if they failed to have cross-licensing agreements in place. Negotiating such agreements was greatly facilitated by having a large patent portfolio of your own, so several firms, large and small, were engaged in defensive drives to increase their patenting rate. This had little to do with encouraging innovation, and in fact looked like a tax on innovative activity. The result also highlights the fact that the one product/one patent model of innovation is very far from the reality in many industries.

Hall and Ziedonis (2001) also noted another effect of stronger patents in the semiconductor industry: it appears to have facilitated the entry of pure "design" firms, those which produce semiconductor designs but do no manufacturing. This fact was supported both by interview evidence (executives reported that patents were important for securing venture capital financing where there were few other assets) and by the fact that the share of design firms in the industry went from approximately zero per cent in 1982 (before the strengthening of the system) to 30 per cent in 1995.

Several conclusions emerge from this survey of empirical work on the effects of the patent system on innovation. Although introducing or strengthening a patent system (lengthening the patent term, broadening subject matter coverage, and so forth) usually results in an increase in patenting, it is not clear that these changes result in an increase in innovative activity at all times and in all places. If there is an increase in innovation due to patents, it is most likely to be centered in the pharmaceutical, biotechnology, and medical instrument sectors, and possibly also specialty chemicals. Patents in many of these areas are relatively easy to define, because they are based on molecular formulas, and therefore also relatively easy to enforce. Thus empirical research supports those who argue that a unitary patent system is far from optimal for supporting innovation.

The most interesting and not immediately obvious conclusion is that the existence and strength of the patent system has a tendency to affect the organization of industry, by allowing trade in knowledge and facilitating the vertical disintegration of knowledge-based industries and the entry of new firms that possess only intangible assets. It is very clear that this particular feature of the patent system has been important with respect to business method and internet patents. In many (but by no means all) cases, the first step taken by an inventor/entrepreneur with an idea for an internet-based business model is to attempt to acquire a patent on it, and certainly one of the first questions asked by the venture capitalist he approaches for financing is whether the startup owns patents on its technology. ${ }^{14}$

${ }^{14}$ See Mann and Sager (2007) for more detail on the use of patents by venture-backed software startups, which is by no means universal, and varies considerably within the software sector. Also see Merges (2003) on the possible implication of financial patents. 


\subsection{Implications for business method innovation}

What does the body of literature just surveyed have to say about the implications of allowing business method patents on innovation in business methods and finance? The only conclusion that is certain is that allowing business method patents will cause an increase in the patenting of business methods, one we have already experienced. And along with this increase in patenting, especially one that introduces patents of less certain quality, comes an increase in litigation, raising the costs of the system as a whole. It is noteworthy that Lerner (2006b) found that the probability of a lawsuit involving a financial patent held by a small entity is above unity, which suggests both that these patents are relatively valuable and that the primary role played by them is the collecting of royalties from other firms. ${ }^{15}$ Overall, he found that the lawsuit rate for financial patents awarded between 1976 and 2003 was about 30\%, to be compared with the relatively low overall rate of 1-2\% reported by Lanjouw and Schankerman (2001). As Farrell and Shapiro (2008) have shown, even weak patents whose validity is uncertain can be surprisingly effective in litigation.

Unfortunately, although we can be confident that the use of patents will increase when they are allowed, it is much more difficult to make predictions about the effects of this subject matter expansion on innovation that are not pure speculation. We know that patents are not considered essential for capturing the returns to innovation in many industries, and there seems no reason to think that this one is different. Casual observation suggests that business method patents are not being used to provide innovation incentives as much as they are being used to extract rents ex post, but this evidence could be misleading. We do not know whether there would have been as much entry into internet businesses or new financial offerings in the absence of the patent system, or even whether such entry is a good or a bad thing (recent difficulties among innovative financial firms suggest the latter possibility).

A recent study by Duffy and Squires (2008) discusses the tradeoff between secrecy and patenting for financial innovations in sophisticated trading mechanisms, valuation metrics, or innovative financial products, suggesting that as transparency becomes more important to regulators, the desirability of patenting may increase. However, at the present time, such inventions are not generally protectable outside the US, so patenting is less attractive, as it enables easy imitation of an intangible product that can be produced anywhere in the world. Duffy and Squires then looked at 100 patents issued in class 705/35 (Finance - banking, investment, or credit) during 2008 and concluded that only a handful were for such sophisticated new financial products, suggesting that either that these are not yet being patented, or that

\footnotetext{
${ }^{15}$ More precisely, Lerner found that firms with employment less than 200 in the year a patent was awarded experienced 1.153 lawsuits per patent, adjusted for the grant and suit lags.
} 
they are still stuck in the patent office. ${ }^{16}$ Kumar and Turnbull (2008) provide a model of the decision to patent in this case, suggesting that it depends to a great extent on the extent to which there is a need to develop a market for the new product, which would involve revealing the idea to potential imitators.

In a slightly different technology area, one possible evolution of practice in the banking and financial services industry can be hypothesized, however. This industry depends heavily on secure communication and transactions exchange among banks and brokerage houses, and such communications depend on standards, that is, they depend on different institutions communicating information to each other in exactly the same way. The industry carries out millions of such transactions daily and requires a very high level of accuracy, which implies a need for highly stable common standards. If components of new transactions' standards or particular ways of doing things are patented by many different institutions, it is possible that a situation could develop like that in the semiconductor/computer industry, where it is necessary to have a portfolio of patents for cross-licensing purposes. This in turn may raise the cost of doing business and make it harder for new firms to enter without access to the requisite intellectual property.

I close this discussion with the observation by Merges (2003) about the potential consequences of the introduction of patenting into the financial sector, which has not been welcomed by the established large players in that sector. According to Merges, two other U.S. industries (railroads in the $19^{\text {th }}$ century and commercial software in the $20^{\text {th }}$ ) have previously greeted the arrival of patents on a large scale in their sectors with alarm and then learned to live with them, with no obvious decline in innovative activity or even profitability. As he puts it, "Perhaps patents overall simply do not affect the 'big variables' of economic life - industry structure, the basic pace of innovation, etc. - in such an industry to any great extent." (Merges 2003, page 21).

\section{$4 \quad$ Patent quality ${ }^{17}$}

Many critics of the wave of business method patents in the first couple of years following the State Street decision have pointed to their low quality rather than their existence as the real policy problem (see Barton 2000, Dreyfuss 2001, and other references in Table 4). But what is meant by patent quality? The statutory definition of a patentable invention is that it be novel, non-obvious, and have utility. ${ }^{18}$ Both the economic and legal view suggest that high quality patents are those which describe an

${ }^{16}$ Note that because this type of patent is unlikely to be applied for outside the US and therefore will not be published at 18 months after application, the current seven year pendency means that a number of applications could be pending and not yet observed.

${ }^{17}$ Parts of this section are drawn from Hall et al. (2003).

${ }^{18}$ See Lunney (2001) for an argument that the non-obviousness test has been weakened since the creation 
invention that is truly "new," rather than an invention that is already in widespread use but not yet patented. ${ }^{19}$

Besides the three statutory requirements, a fourth criterion for granting a patent on an invention is that the patent application must disclose sufficient details about the invention. These disclosures in the published patent can facilitate knowledge spillovers to others who might use or improve upon the invention. Another criterion for a "high-quality patent" therefore is that it enable those "skilled in the art" to comprehend the invention well enough to use the patent document for implementation of the described invention. This dimension of patent quality, however, is less likely to be affected by post-grant opposition proceedings.

From a social welfare perspective, an important characteristic of a high quality patent is that there be relatively little uncertainty over the breadth of its claims, i.e., over what specific features of a technical advance are claimed under the terms of the patent, as well as whether these claims are likely to be upheld in legal proceedings following the issue of the patent. Uncertainty about the validity of a patent has several potential costs: such uncertainty may cause the patentholder to underinvest in the technology, it could reduce investment by potential competitors in competing technical advances, and it may lead to costly litigation after both the holder and potential competitors have sunk sizable investments. A recent book by Bessen and Meurer (2008) argues very clearly that lack of clear notice renders the patent right very unlike an ordinary real property right.

\subsection{Consequences of low patent quality}

Although some scholars, notably Lemley (2001), have argued that the costs of having higher quality patents may exceed the cost, recent experience suggests that there are some unintended consequences in the form of complicating property rights and feedback effects. In this section we review the arguments for increasing patent quality.

"Low-quality patents" can create considerable uncertainty among inventors or would-be commercializers of inventions and slow either the pace of innovation or investment in the commercialization of new technologies. Lerner (1995) has shown that fear of litigation may cause smaller entrant firms to avoid areas where incumbents hold large numbers of patents. Such "entry-avoidance" may be rational and even welfare-enhancing if the incumbents' patents are known for certain to be valid, but low quality patents held by incumbents may also deter entry into a technological area if the costs of invalidating the patents is too high. In these circumstances, technological alternatives may not be

of the Federal Circuit Court of Appeals in 1982.

${ }^{19}$ Presumably, if the invention has already been reduced to practice by others, the potential gain from incenting an inventor is zero, so we are left only with the deadweight loss from monopoly. 
commercialized and consumer welfare suffers. Also, as Farrell and Shapiro (2008) argue, they can harm consumer welfare if used restrain downstream competition.

The lack of relatively rapid processes for resolving patent validity and ensuring higher patent quality also may slow the pace of invention in fields characterized by "cumulative invention," i.e., those in which one inventor's efforts rely on previous technical advances or advances in complementary technologies. But if these previous technical advances are covered by patents of dubious validity or excessive breadth, the costs to inventors of pursuing the inventions that rely on them may be so high as to discourage such "cumulative" invention. Alternatively, large numbers of low-quality patents may dramatically increase the level of "fragmentation" of property rights covering prior-generation or complementary technologies, raising the transaction costs for inventors of obtaining access (e.g., through licenses) to these technologies (Shapiro 2001). Finally, the issue of a large number of low-quality patents will increase uncertainty among inventors concerning the level of protection enjoyed by these related inventions, which in turn will make it more costly and difficult for inventors to build on these related inventions in their own technical advances.

The issuance of low-quality patents also is likely to spur significant increases in patent applications, further straining the already overburdened examination processes of the USPTO. A kind of vicious circle may result, in which cursory examinations of patent applications result in the issue of lowquality patents, which triggers rapid growth in applications, further taxing the limited resources of the USPTO, further limiting the examination of individual applications, and further degrading the quality of patents.

Decisions in the early 2000s by the Court of Appeals for the Federal Circuit (CAFC), the specialized appeals court for patent cases, concerning the validity of "important" patents (those deemed sufficiently valuable by patentholder or competitor to litigate and appeal) create still another reason for serious consideration of a nonjudicial process for post-issue validity challenges. For example, in 2002 the CAFC ruled that the PTO had incorrectly rejected two applications for "obviousness," arguing that if an examiner rejects an application using "general knowledge," that knowledge "must be articulated and placed on the record. ${ }^{, 20}$ At the time, according to deputy commissioner Esther Kepplinger, this meant "we can't reject something just because it's stupid." ${ }^{21}$ It is possible that decisions like this significantly weakened the level of scrutiny provided by the already costly and overcrowded patent-litigation system.

\footnotetext{
${ }^{20}$ This decision presumably made it more difficult to reject such patents as US 6368227, the patent on a swinging method that uses a technique known by children for years, but not placed "on the record." Note that this particular patent has been subject to a re-examination request of the U.S. Patent Commissioner because of the publicity it received. The problem with patents like this is not necessarily that they are enforceable in the courts, but that they clog the system and raise its total cost.

${ }^{21}$ As quoted on the Los Angeles Times, February 7, 2003.
} 
The USPTO has responded both to critics of the quality of patents being issued and the increasing flood of patent applications in a number of ways. First, they introduced a second pair of eyes for the examination of business method patents in March 2000 and later extended it to other new technology areas. Second, in 2007, together with the Peer-to-patent project at the New York University Law School, they begin a pilot program that allows third parties to submit prior art for selected patent applications in the computing and business method areas that are in the system but not yet examined. It is clear that these initiatives have had some effect, both on the decline of 705 patents issuing that is visible in the data, and in the initial patent allowance rate, which has fallen from $70 \%$ in 2001 to $45 \%$ in 2008 (Crouch 2009).

Finally, then Commissioner Dudas proposed a series of rules changes in 2008 that were designed to reduce the USPTO workload by discouraging continuation applications, requests for continued examinations, and applications with large numbers of claims. After litigation by inventors opposed to these changes, the CAFC allowed at least some of them to stand (Foley \& Lardner LLP 2009).

\section{Survey of policy recommendations}

This section of the paper collects and organizes the many policy recommendations with respect to business method, internet, and software patents that have been made by other scholars, in an effort to find a consensus. Table 4 summarizes the recommendations of a number of legal and economic scholars. Several points emerge from this table and from a reading of the papers referenced.

First, there is a remarkable amount of agreement, if not a consensus, that the average quality of patents being issued during the 1990s was too low, especially in the software and business method areas. There is also some agreement on the reasons: an overburdened patent office, lack of expertise in the relevant areas, lack of prior art databases, and the weakening of the non-obviousness test, partly through court decisions.

Recommendations center on correcting these problems in software and business methods, although many of the suggestions would apply more broadly. Many authors suggest that standards of patentability and non-obviousness should be raised across all technologies, but especially in software and business methods (Barton 2000, 2001, Kasdan 1994, Bakels and Hugenholtz 2002, Lunney 2001, Quillen 2001, Dreyfuss 2001, Meurer 2002). This recommendation appears to have been followed to some extent by the USPTO after about 2001, and was reinforced by the Supreme Court decision in KSR v Teleflex. ${ }^{22}$

On the other hand, there is considerable variation in the recommendations with respect to subject matter extensions to software and business methods, ranging all the way from the AIPLA position that business methods receive the same treatment as other technologies to Thomas' 1999 recommendation that

${ }^{22}$ KSR v. Teleflex, 550 U.S. 398 (2007). 
subject matter be restricted to "the repeatable production or transformation of material objects." Nevertheless, a number of legal scholars, including Dreyfuss, Meurer, and Bakels and Hugenholtz, have called for reinstatement of the business method exception. Again, to a limited extent this has happened with the Bilski decision.

With respect to software more broadly, Lemley and O'Brien (1997) and Somaya (2001) have argued that patenting of software may have a beneficial effect if it leads to the reuse rather than the reinvention of software components as a result of patent publication rather than the use of secrecy to protect them. However, Lemley himself, along with Cohen, Warren-Boulton et al (1995), and Samuelson (1995) have recommended both narrow construction of patents for software and limited rights to reverse engineer in order to ensure interoperability and transparent interfaces.

Finally, several authors have endorsed the idea that a greatly strengthened inter partes post grant re-examination system modeled on the European opposition system would encourage competitors and other third parties to bring forth prior art, especially in new subject matter areas where the PTO has inadequate searching facilities (Janis 1997, Levin and Levin 2002, Graham et al 2003, Hall et al 2003, Wegner 2001). The primary argument for such a system is that it would lead to invalidity determinations being made earlier and at less cost than the current system, which relies primarily on infringement suits accompanied by countersuits for patent validity. A second argument is that by housing validity determination within the patent office, useful feedback on the performance and accuracy of examination can be generated relatively quickly and communicated at somewhat lower cost than if it is generated by the courts. I refer the reader to Graham et al (2003) for further information on the comparative operation of the ex parte U.S. re-examination system and the inter partes European opposition system.

\section{Conclusions}

Broad evidence that the patent system encourages innovation always and everywhere is hard to come by. The patent system does encourage publication rather than secrecy; it is probably good at providing incentives for innovations with high development cost that are fairly easily imitated and for which a patent can be clearly defined (e.g., pharmaceuticals). When innovations are incremental and when many different innovations must be combined to make a useful product, it is less obvious that benefits of the patent system outweigh the costs. Business and financial methods are more likely to fall into the second class than the first.

It is useful to think about recommendations for policy towards business methods patents in two very distinct levels: first, there is widespread agreement among legal scholars that the nonobviousness test has not been applied carefully enough in the case of internet and business method patents and that lack of prior art databases have led to many invalid patents issuing in software and business methods. Second, 
some scholars go further and argue that business methods per se should be excluded from patentability, Judge Rich not withstanding. Given the number of such patents now outstanding, this outcome is unlikely.

With respect to the former critique, a number of scholars have advanced the use of a strengthened post-grant re-examination system in order to encourage third parties to bring prior art to the attention of the patent office. Although the PTO recently strengthened the examination process with respect to these patents (USPTO 1999), some believe that this proposal still has some merit, especially if it could be used to weed out patents in these areas that were issued prior to the administrative changes at the patent office. In the meantime, legal decisions and the USPTO's own actions seem to have mitigated the problems that arose following the State Street decision.

Excluding business and financial methods per se from patentability, although perhaps desirable, is not really feasible given the difficulty of defining what they are. Even at the EPO, where there is a general exclusion, such patents do exist whenever the invention solves a particular technical problem. The language in the recent Bilski decision in the United States seems to move in that direction, and to exclude those patents with overbroad and vague claims which are perceived by many to be the main drag on the innovative system.

\section{References}

Allison, J. R. and E. H. Tiller (2003). "Statistical Analysis of Internet Business Method Patents," in Cohen, W. M. (ed.), Intellectual Property in the Knowledge-Based Economy. Washington, DC: National Academies Press.

Arora, A., M. Ceccagnoli, and W. Cohen (2003). "R\&D and the Patent Premium." Cambridge, MA: NBER Working Paper No. W9431.

Arundel, A. (2001). "Patents in the Knowledge-Based Economy," Beleidstudies Technology Economie 37: 67-88.

Bakels, R. and P. B. Hugenholtz (2002). "The Patentability of Computer Programs," Amsterdam: IViR.

Barton, J. H. (2001). “Non-Obviousness.” Stanford University Law School (August). . (2000). "Reforming the Patent System," Science 287: 1933-1934.

Bessen, J. E. and E. Maskin (2006). "Sequential Innovation, Patents, and Imitation." Princeton, NJ: Institute for Advanced Study, School of Social Science.

Bessen, J. E. and M. J. Meurer (2008). Patent failure: How judges, bureaucrats, and lawyers put innovators at risk. Princeton, NJ: Princeton University Press. 
Blind, K., J. Edler, and R. Nack (2001). "Micro- and Macro-economic Implications of the Patentability of Software Innovations. Intellectual Property Rights in Information Technologies between Innovation and Competition," Karlsruhe/Munich: Fraunhofer Institute and Max Planck Institute.

Cockburn, I. (2001). "Issues in Business Method Patents," Boston University and NBER.

Cohen, J. E. and M. A. Lemley (2001). "Patent Scope and Innovation in the Software Industry," California Law Review 89(1): 1-57.

Cohen, W. M., R. R. Nelson, and J. P. Walsh (2000). "Protecting Their Intellectual Assets: Appropriability Conditions and Why Firms Patent or Not?” NBER Working Paper No. 7552

Crouch, D. (2009). Patently-O Blog. http://www.patentlyo.com/

Davis, L. (2002b). "Is Appropriability a "Problem” for Innovations in Digital Information Goods?" In G. Eliasson and C. Wihlborg (eds.), The Law, Economics and Technology of the Internet, unknown publisher.

(2002a). "Patents and the Internet." In G. Eliasson and C. Wihlborg (eds.), The Law, Economics and Technology of the Internet, unknown publisher.

Diallo, B. (2003). "Historical perspectives on IP protection for software in selected countries worldwide," World Patent Information 25: 19-25.

Dreyfuss, R. C. (2001). "Examining State Street Bank: Developments in Business Method Patenting," Computer und Recht International 2001(1): 1-9. . (2000). "State Street or Easy Street: Is Patenting Business Methods Good for Business?” In Intellectual Property Law, Volume 6, Chapter 14. London: Juris Publishing Company, Ltd. Duffy, J.F. Squires, J.A. (2008). “Disclosure and Financial Patents: Revealing the Invisible Hand.” Paper presented at the Bank of Finland-CEPR Conference, Helsinki, October 2008.

European Commission. (2002). "Proposal for a Directive of the European Parliament and of the Council on the Patentability of Computer-implemented Inventions," Brussels, Belgium.

Farrell, J. and C. Shapiro (2008). "How Strong Are Weak Patents?” American Economic Review 98 (4): $1347-69$.

Federal Trade Commission (2003). To Promote Innovation: The Proper Balance of Patent and Competition Law Policy. Washington, DC: GPO, October.

Foley \& Lardner, LLP (2009). "Did the Patent Office Win? Tafas v. Doll Opens the Door to Substantial Changes in the USPTO's Practice, But Finds That Limits on Continuation Applications Exceed USPTO Authority.” Legal News Alert, March 2009. http://www.foley.com/publications/pub_detail.aspx?pubid=5859, accessed 30 March 2009. 
Graham, S. J. H. and D. C. Mowery (2003). "Intellectual Property Protection in the U.S. Software Industry." In W. M. Cohen and S. A. Merrill (eds.), The Patent System in the Knowledge-Based Economy. Washington, DC: National Academies Press.

Graham, S. J. H., B. H. Hall, D. Harhoff, and D. C. Mowery (2003). "Post-Issue Patent Quality Control: A Comparative Study of US Patent Re-Examinations and European Patent Oppositions." In W. M. Cohen and S. A. Merrill (eds.), The Patent System in the Knowledge-Based Economy. Washington, DC: National Academies Press, pp. 74-119.

Green, J. and S. Scotchmer. (1995). "On the Division of Profit in Sequential Innovation," Rand Journal of Economics 26: 20-33.

Grindley, P.C and Teece, D.J. (1997). "Managing Intellectual Capital: Licensing and CrossLicensing in Semiconductors and Electronics," California Management Review 39: 1-34.

Hall, B. H. (2007). "Innovation in non-bank payment systems." Paper presented at the Kansas City Federal Reserve Conference, Santa Fe, NM, May 2007.

Hall, B. H. (2003). "Business Method Patents, Innovation, and Policy." Cambridge, MA: NBER Working Paper w9717.

Hall, B. H., S. J. H. Graham, D. Harhoff, and D. C. Mowery. (2003). "Prospects for Improving

U.S. Patent Quality via Post-grant Opposition.” Innovation Policy and the Economy 4: 115-43.

Hall, B. H., and M. MacGarvie (2006). "The Private Value of Software Patents,” Cambridge, Mass.: NBER Working Paper w12195 (April).

Hall, B. H., G. Thoma, and S. Torrisi (2009). "Financial patenting in Europe.” European Management Review, forthcoming.

Hall, B. H., and R. H. Ziedonis (2001). "The Patent Paradox Revisited: An Empirical Study of Patenting in the U.S. Semiconductor Industry, 1979-1995," Rand Journal of Economics 32:101-128.

Hart, P., P. Holmes, J. Reid. (1999). The Economic Impact of Patentability of Computer

Programs, London: Intellectual Property Institute.

Heller, M.A. and R.S. Eisenberg. (1998). "Can Patents Deter Innovation? The Anticommons in Biomedical Research," Science 280: 698-701.

Hunt, R. M. (2008). “Business Method Patents and U.S. Financial Services.” Research Department Working Paper No. 07-21. Philadelphia, PA: Federal Reserve Bank of Philadelphia. . (2001a). "Patentability, Industry Structure, and Innovation." Philadelphia, PA:

Federal Reserve Bank of Philadelphia Research Dept. Working Paper No. 01-13. (2001b). "You Can Patent That? Are Patents on Computer Programs and Business Methods Good for the New Economy?" Philadelphia Federal Reserve Bank Business Review 2001(Q1): $5-15$. 
. (1999). "Nonobviousness and the Incentive to Innovate: An Economic Analysis of

Intellectual Property Reform,” FRB-Philadelphia Research Department Working Paper No. 99-3.

Janis, M. D. (1997). "Rethinking Reexamination: Toward a Viable Administrative Revocation

System for U.S. Patent Law," Harvard Journal of Law and Technology 11 (1): 1-122.

Kanwar, S. and R. Evenson (2003). "Does Intellectual Property Protection Spur Technical Change?" Oxford Economic Papers 55: 235-64.

Kasdan, J. (1999). “Obviousness and New Technologies,” New York, NY: Columbia University Center for Law and Economics Studies Working Paper No. 146.

. (1994). “Fascinatin’ Algorithm: Patent Protection for Computer Programs," Columbia

University Center for Law and Economic Studies Working Paper No. 94.

Kingston, W. (2001). “Innovation Needs Patents Reform.” Research Policy 30 (3): 403-423.

Kumar, P and S. M. Turnbull (2008). "Optimal Patenting and Licensing of Financial

Innovations." Management Science 54 (12): 2012-23.

Lanjouw, J. O. and M. Schankerman (2001). "Characteristics of Patent Litigation: A Window on Competition." Rand Journal of Economics 32 (1): 129-51.

Lemley, M. A. (2001). "Rational Ignorance at the Patent Office," Northwestern University Law Review 95 (4): 1495-1532.

Lemley, M. A. and D. W. O'Brien (1997). “Encouraging Software Reuse.” Stanford Law Review 49(2): ------.

Lerner, J. (2006a). "The New New Financial Thing: The Origins of Financial Innovations."

Journal of Financial Economics 79 (2): 223-55.

. (2006b). "Trolls on State Street?: The Litigation of Financial Patents, 1976-2005."

Boston, MA: Harvard Business School, manuscript. . (2002). "Patent Protection and Innovation over 150 Years." American Economic

Review 92 (2): 221-25.

. (2001). “Where Does State Street Lead?” Harvard Business School Working Paper

No. 01-005. (1995). "Patenting in the Shadow of Competitors," Journal of Law and Economics

38(2): 463-496.

Levin, R. C., A. K. Klevorick, R. R. Nelson, and S. G. Winter. (1987). “Appropriating the Returns to Industrial R\&D,” Brookings Papers on Economic Activity: 783-820.

Levin, R. C. and J. Levin. (2002). "Patent Oppositions," Yale University and Stanford University Working Paper No. (March). 
Lunney, G. S., Jr. (2001). “e-Obviousness,” Michigan Telecommunications Technology Law Review 7: 363-422.

Managing Intellectual Property (2008). "EPO to address software patentability." Weekly News,

October 24. http://legalmediagroup.com/news

Managing Intellectual Property (2008). "Federal Circuit clarifies test for business method

patents." Weekly news, October 31. http://legalmediagroup.com/news

Managing Intellectual Property (2007). "A sliver of hope for UK software patents.” Weekly News,

June 1. http://legalmediagroup.com/news

Managing Intellectual Property (2004). "UK acts over business method applications." Weekly

News, November 28. http://legalmediagroup.com/news

Mann, R. J. and T. W. Sager (2007). "Patents, Venture Capital, and Software Startups.” Research Policy 36: 193-208.

Mansfield, E. (1986). "Patents and Innovation: An Empirical Study," Management Science 32: $173-81$

Mazzoleni, R. and R. R. Nelson (1998). "Economic Theories about the Benefits and Costs of Patents" Journal of Economic Issues 32(4): 1031-1052.

Merges, R. P. (2003). “The Uninvited Guest: Patents on Wall Street.” Berkeley, CA: University of California at Berkeley Public Law Research Paper No. 126. 1999. “As Many As Six Impossible Patents Before Breakfast: Property Rights for Business Concepts and Patent System Reform.” Berkeley Technology Law Journal 14 (2): 577-616.

Meurer, M. J. (2002). "Business Method Patents and Patent Floods," forthcoming in the Washington University Journal of Law and Policy.

Moser, P. (2005). “How Do Patent Laws Influence Innovation? Evidence from NineteenthCentury World's Fairs.” American Economic Review 95 (4): 1214-36.

National Research Council (2004). A Patent System for the 21st Century, Report of the Board on Science, Technology, and Economic Policy. Washington, DC: National Academies Press.

O'Donoghue, T. (1998). “A Patentability Requirement for Sequential Innovation,” Rand Journal of Economics 29 (4): 654-679.

Park, W. G., and J. C. Ginarte (1997). "Intellectual Property Rights and Economic Growth," Contemporary Economic Policy XV (July): 51-61.

Qian, Y. (2007). "Do Additional National Patent Laws Stimulate Domestic Innovation in a Global Patenting Environment." Review of Economics and Statistics 89 (3): 436-53.

Quillen, C. D., Jr. 2001. “The U.S. Patent System: Is it Broke? And Who Can Fix it, if it is? Presentation to the AGC. 
Sakakibara, M., and L. Branstetter (2001). "Do Stronger Patents Induce More Innovation? Evidence from the 1988 Japanese Patent law Reforms," Rand Journal of Economics 32: 77-100.

Samuelson, P. (1995). “An Entirely New Legal Regime is Needed,” The Computer Lawyer 12 (2): 11-17.

Scotchmer, S. (1996). "Protecting Early Innovators: Should Second Generation Products be Patentable?," Rand Journal of Economics 27: 322-331. . (1991). "Standing on the Shoulders of Giants: Cumulative Research and the Patent Law," Journal of Economic Perspectives. 5: 29-41.

Shapiro, C. (2001). "Navigating the Patent Thicket: Cross Licenses, Patent Pools, and StandardSetting." Innovation Policy and the Economy 1: 119-50.

Somaya, D. (2001). "Incentives, Organizational Choices and Transactional Challenges in Software Production," College Park, MD: University of Maryland.

Spindler, G.. (2003). "The European Legal Framework for Software Patents," paper presented at the EPIP conference on New Challenges to the Patent System, EPO, Munich, Germany, April 24/25, 2003.

State Street Bank and Trust Co., Inc. v. Signature Financial Group, Inc., 149 F.3d 1368 (Fed. Cir. 1998).

Takalo, T. and M. Komulainen. (2008). "Empirical Study of European patent applications in class G06Q 40/00B Exchange.” Manuscript.

Thomas, J. R. (1999). “The Patenting of the Liberal Professions.” Boston College Law Review. 40: 1139-1190.

Tufano, P. (1989). "Financial innovation and first-mover advantages.” Journal of Financial Economics 25: 213-240.

. (2003). "Financial innovation." In Costantinides et al (eds), Handbook of the Economics of Finance. Amsterdam: Elsevier: 307-335.

USPTO. (1999). "White Paper on Automated Financial or Management Data Processing Methods (Business Methods),"<http://www.uspto.gov/web/menu/busmethp/index2.htm>.

U.S. Supreme Court website. http://www.supremecourtus.gov

Wagner, S. (2008). "Business Method Patents in Europe and their Strategic Use - Evidence from Franking Device Manufacturers." Economics of Innovation and New Technology 17 (3-4): 173-94.

Warren-Boulton, F. R., K. C. Baseman and G. A. Woroch. (1995). "Copyright Protection of Software Can Make Economic Sense," The Computer Lawyer 12 (2): 18-28. 
Wegner, H. C. (2001). "Invalidity Defenses to e-patent Infringement: A Comparative View of the Differing Ways to Achieve Patent Justice in the United States," Paper presented at the SOFTIC 2001 Symposium, Tokyo, Japan. 


\section{Table 1}

Costs and benefits of the patent system

\begin{tabular}{|c|c|c|}
\hline Effects on & Benefits & Costs \\
\hline Innovation & $\begin{array}{l}\text { creates an incentive } \\
\text { for R\&D; } \\
\text { promotes the diffusion } \\
\text { of ideas }\end{array}$ & $\begin{array}{l}\text { impedes the } \\
\text { combination of new } \\
\text { ideas and inventions; } \\
\text { raises transaction } \\
\text { costs }\end{array}$ \\
\hline Competition & $\begin{array}{l}\text { facilitates entry of new } \\
\text { small firms with limited } \\
\text { assets; } \\
\text { allows trading of } \\
\text { inventive knowledge - } \\
\text { markets for technology }\end{array}$ & \begin{tabular}{|l|} 
creates short-term \\
monopolies, which \\
may become long-term \\
in network industries
\end{tabular} \\
\hline
\end{tabular}


TABLE 2

Selected Software and Business Method Patent Disputes

\begin{tabular}{|c|c|c|c|c|c|c|c|c|c|}
\hline $\begin{array}{c}\text { Patent } \\
\text { number }\end{array}$ & $\begin{array}{c}\text { Patent } \\
\text { class }\end{array}$ & $\begin{array}{l}\text { Issue } \\
\text { Date }\end{array}$ & Description & Plaintiff & Defendant & Date Filed & Court & $\begin{array}{c}\text { Date } \\
\text { Outcome of } \\
\text { Action }\end{array}$ & Outcome \\
\hline \multicolumn{10}{|c|}{ Infringement suits } \\
\hline 4873662 & 711 & 1989 & Hyperlink prototype patent & British Telecom & Prodigy (AOL, etc) & Dec 2000 & New York & Sept 2002 & $\begin{array}{l}\text { Summary judgement; patent not valid; BT abandoned } \\
\text { patent }\end{array}$ \\
\hline 5193056 & $705 / 36$ & 1993 & $\begin{array}{l}\text { Data processing system for hub and } \\
\text { spoke financial services } \\
\text { configuration }\end{array}$ & State Street & Signature Financial & 1994 & Mass. & 1998 & State Street prevailed; business methods are patentable \\
\hline 5267314 & 713 & 1993 & Public key encryption (SSL) & Leon Stambler & \begin{tabular}{|l|} 
RSA Security, \\
Verisign, etc \\
\end{tabular} & Feb 2001 & Delaware & & Trial began $2 / 26 / 03$ \\
\hline 5333184 & 379 & 1994 & $\begin{array}{l}\text { Call message recording for } \\
\text { telephone systems (use of an } \\
\text { algorithm to assing billing codes of } \\
\text { IXCs in customer's records) }\end{array}$ & $A T \& T$ & $\begin{array}{l}\text { Excel } \\
\text { Communications }\end{array}$ & 1998 & & April 1999 & $\begin{array}{l}\text { CAFC reversed summary judgement, remanded to district } \\
\text { court }\end{array}$ \\
\hline 5845265 & $705 / 37$ & 1995 & $\begin{array}{l}\text { computerized market place for } \\
\text { goods }\end{array}$ & MercExchange & Return Buy & Sept 2001 & VA, Eastern & Dec. 2002 & $\begin{array}{l}\text { ReturnBuy settled for non-exclusive license, details not } \\
\text { disclosed }\end{array}$ \\
\hline 5774870 & $705 / 14$ & 1998 & Online incentive/award systems & Netcenter & $\begin{array}{l}\text { Carlson Companies; } \\
\text { others }\end{array}$ & & CA, Northern & & $\begin{array}{l}14 \text { licensees with royalties of } \$ 6,000,000 \text { per year } \\
\text { collected by Netcenter }\end{array}$ \\
\hline 5794207 & $705 / 1$ & 1998 & $\begin{array}{l}\text { (Dutch auction) method and } \\
\text { apparatus for cryptographically } \\
\text { assisted commercial network } \\
\text { system designed to facilitate buyer- } \\
\text { driven conditional purchase offers }\end{array}$ & $\begin{array}{l}\text { Priceline/Walker } \\
\text { Digital }\end{array}$ & Microsoft/Expedia & Oct 1999 & Connecticut & Jan 2001 & Settled with undisclosed royalty payments \\
\hline 5960411 & $705 / 26$ & 1999 & One-click internet shopping & Amazon.com & Barnes and Noble & Oct 1999 & Washington & Mar 2002 & Settled with royalties to Amazon.com \\
\hline 6009412 & $705 / 14$ & 1999 & online incentive/award systems & Netcentives/Netcenter & $\begin{array}{l}\text { Carlson Companies; } \\
\text { others }\end{array}$ & & CA, Northern & & $\begin{array}{l}14 \text { licensees with royalties of } \$ 6,000,000 \text { per year } \\
\text { collected by Netcentives }\end{array}$ \\
\hline $\begin{array}{l}5848265 ; \\
6085176 ; \\
6202051\end{array}$ & $705 / 37$ & 2000 & $\begin{array}{l}\text { Use software search agents to } \\
\text { comb multiple marketplaces; } \\
\text { automated auctions }\end{array}$ & MercExchange & eBay & Sept 2001 & VA, Eastern & 2006 & $\begin{array}{l}\text { Supreme Court overturned CAFC injunction; settled with } \\
\text { undisclosed royalty payments in Feb. } 2008\end{array}$ \\
\hline 5897620 & $705 / 5$ & 1999 & $\begin{array}{l}\text { (Dutch auction) method and } \\
\text { apparatus for the sale of airline- } \\
\text { specified flight tickets }\end{array}$ & $\begin{array}{l}\text { Priceline/Walker } \\
\text { Digital }\end{array}$ & Microsoft/Expedia & Oct 1999 & Connecticut & Jan 2001 & Settled with royalties not disclosed. \\
\hline \multicolumn{10}{|c|}{ Selected re-examination requests } \\
\hline 5806063 & 707 & 1998 & Y2K century windowing & \begin{tabular}{|l|} 
McDonnell \\
Douglas/Bruce \\
Dickens \\
\end{tabular} & & 1999 & & & $\begin{array}{l}\text { Licensing letters 1999-2000; USPTO re-examined at } \\
\text { inventor and PTO request, no outcome as of Feb. } 2003\end{array}$ \\
\hline 6368227 & 472 & 2002 & $\begin{array}{l}\text { swinging a swing sideways or in a } \\
\text { circular motion instead of back and } \\
\text { forth by pulling on the chains }\end{array}$ & Steven Olson & & 2003 & & & USPTO-requested re-exam; no outcome noted. \\
\hline \multicolumn{10}{|c|}{ Examples of licensing letters requesting royalties } \\
\hline 5241671 & 707 & 1993 & $\begin{array}{l}\text { Multi-media search sustem with } \\
\text { multiple paths (broad claims) }\end{array}$ & \begin{tabular}{|l|} 
Compton's \\
Encyclopedia / \\
Britannica \\
\end{tabular} & & & & July 2003 & $\begin{array}{l}\text { Re-examined at PTO request Dec/93, certificate issued } \\
\text { July } 2002 \text { (!), with narrowed claims }\end{array}$ \\
\hline $\begin{array}{r}5933841 \\
6442574\end{array}$ & $\begin{array}{l}715 \\
\text { (was } \\
707)\end{array}$ & 1999 & Structured document browser & $\begin{array}{l}\text { SBCommunications/A } \\
\text { meritech }\end{array}$ & 30 licensing letters & Feb 2003 & & & $\begin{array}{l}\text { prior art: Netscape } 2.0 \text { (1995); OWL International (1988) - } \\
\text { first commercial hypertext system }\end{array}$ \\
\hline
\end{tabular}


TABLE 3

\section{Patent Classes with Software or Business Method Patents}

\begin{tabular}{|c|l|}
\hline Class & Description \\
\hline 380 & Cryptography \\
382 & Image Analysis \\
395 & Information Processing System Organization \\
\hline 700 & Data Processing: Generic Control Systems or Specific Applications \\
701 & Data Processing: Vehicles, Navigation, and Relative Location \\
702 & Data Processing: Measuring, Calibrating, or Testing \\
703 & Data Processing: Structural Design, Modeling, Simulation, and Emulation \\
& Data Processing: Speech Signal Processing, Linguistics, Language \\
\hline 704 & Translation, and Audio Compression/Decompression \\
\hline 705 & Data Processing: Financial, Business Practice, Management, or Cost/Price \\
\hline 706 & Determination \\
\hline 707 & Data Processing: Artificial Intelligence \\
& Data Processing: Database and File Management, Data Structures, or \\
709 & Elecument Processing \\
\hline 710 & or Process Coordinating \\
711 & Electrical Computers and Digital Data Processing Systems: Input/Output \\
712 & Electrical Computers and Digital Processing Systems: Memory \\
713 & Electrical Computers and Digital Processing Systems: Processing \\
715 & Architectures and Instruction Processing (e.g., Processors) \\
717 & Electrical Computers and Digital Processing Systems: Support \\
\hline 902 & Data Processing: Presentation Processing of Document \\
\hline
\end{tabular}


TABLE 4

\section{Recent Recommendations on Patent Policy}

\begin{tabular}{|c|c|c|c|}
\hline Author(s) ${ }^{*}$ & Date & Type & Recommendation(s) \\
\hline Dreyfuss & 2001 & $\begin{array}{l}\text { business } \\
\text { method }\end{array}$ & $\begin{array}{l}\text { Prior art search weak; generates low quality patents; Costs of business method patents greatly exceed } \\
\text { benefits and they should be statutorily excluded }\end{array}$ \\
\hline Merges & 1999 & $\begin{array}{l}\text { business } \\
\text { method }\end{array}$ & business method patent flood and low quality patents issuing; calls for opposition system. \\
\hline Meurer & 2002 & $\begin{array}{c}\text { business } \\
\text { method }\end{array}$ & $\begin{array}{l}\text { PTO and the courts should use the subject matter and nonobviousness standards for patentability to limit } \\
\text { grants of business method patents. Favors reversal of State Street and restoration of the business method } \\
\text { exception. Short of reversal, argues for a narrow reading of State Street and rigorous application of the } \\
\text { nonobviousness standard. }\end{array}$ \\
\hline Lunney & 2001 & $\begin{array}{c}\text { business } \\
\text { method }\end{array}$ & $\begin{array}{l}\text { Federal circuit has gone too far in loosening non-obvious test, requiring written documentation. Should limit e- } \\
\text { commerce patents to those that are very creative (i.e., raise patentability standards) }\end{array}$ \\
\hline AIPLA & 2000 & $\begin{array}{l}\text { business } \\
\text { method }\end{array}$ & $\begin{array}{l}\text { Recommends that business methods with useful, concrete or tangible results, including Internet- and } \\
\text { software-implemented business methods, receive the same treatment as other technologies. Where } \\
\text { implemented in software, business method patent applications should be examined as software-related } \\
\text { applications are examined today for compliance with } 35 \text { USC } 101,102,103\end{array}$ \\
\hline Thomas & 1999 & $\begin{array}{l}\text { business } \\
\text { method }\end{array}$ & $\begin{array}{l}\text { Restrict patentable advances to the repeatable production or transformation of material objects, and exclude } \\
\text { subject matter founded upon the aesthetic, social observation or personal skill. Consistent with TRIPS, the } \\
\text { industrial application requirement would restore a sense of patentable subject matter that matches our } \\
\text { sensibilities. }\end{array}$ \\
\hline Wegner & 2001 & $\begin{array}{l}\text { business } \\
\text { method }\end{array}$ & Favors opposition system modeled on Europe and Japan, also designated trail courts for patent cases \\
\hline Bakels and Hugenholtz & 2002 & software & $\begin{array}{l}\text { 1) Stronger inventive step test; 2) Exclude Business Method patents "as such"; 3) Create a European Patent } \\
\text { Observatory to monitor system performance }\end{array}$ \\
\hline Cohen and Lemley & 2001 & software & $\begin{array}{l}\text { 1) Limited right to reverse engineer patented programs, in order to duplicate unprotected elements; 2) Courts } \\
\text { should enforce doctrine of equivalents narrowly for software }\end{array}$ \\
\hline Somaya & 2001 & software & Software components should be reused, as in Lemley and O'Brien \\
\hline Lemley and O'Brien & 1997 & software & $\begin{array}{l}\text { Software patents will encourage the reuse of software components, because trade secrecy no longer } \\
\text { necessary. }\end{array}$ \\
\hline Dam & 1995 & software & $\begin{array}{l}\text { Software patents sound, although badly adminstered by PTO. Sui generis protection for software not } \\
\text { desirable }\end{array}$ \\
\hline Samuelson & 1995 & software & Recommends limited protection for software interfaces (sui generis) \\
\hline $\begin{array}{l}\text { Warren-Boulton, } \\
\text { Baseman, and Woroch }\end{array}$ & 1995 & software & $\begin{array}{l}\text { 1) Copyright should not extend to de facto standards; 2) software interfaces should not be copyrighted, } \\
\text { because of market power extension; 3) allow reverse engineering for interoperability }\end{array}$ \\
\hline Kasdan & 1994 & software & $\begin{array}{l}\text { Lack of computer science personnel among PTO examiners means prior art search incomplete, e.g. Knuth's } \\
\text { book ignored; software patents undesirable }\end{array}$ \\
\hline Kingston & 2001 & general & $\begin{array}{l}\text { Lower cost of patent disputes in complex technologies via 1) Compulsory expert arbitration with legal aid; 2) } \\
\text { Shared-risk compulsory licensing }\end{array}$ \\
\hline Levin and Levin & 2002 & general & Introducing a patent opposition process would give substantial welfare gains \\
\hline Lemley & 2001 & general & $\begin{array}{l}\text { Do not try to improve patent quality by increasing exam time, because PTO is "rationally ignorant," given cost } \\
\text { of higher quality patents }\end{array}$ \\
\hline Quillen & 2001 & general & $\begin{array}{l}\text { 1) Raise standards for patentability; 2) Reduce resulting uncertainty and delay in validity determination; 3) } \\
\text { Reduce excessive damages in patent infringement litigation; 4) Return appellate jurisdiction to regional courts } \\
\text { so alternative views can be heard on the same issue }\end{array}$ \\
\hline Barton & $\begin{array}{l}2000 \\
2001\end{array}$ & general & $\begin{array}{l}\text { 1) Raise standards for patentability by using a real non-obviousness test; } 2 \text { ) Clarify research exemption; } 3 \text { ) } \\
\text { Ease legal attack on invalid patents (strengthen re-exam, remove presumption of validity) }\end{array}$ \\
\hline Janis & 1997 & general & $\begin{array}{l}\text { Recommends an inter partes re-exam system modeled on trademark re-exam and similar to European } \\
\text { opposition system }\end{array}$ \\
\hline
\end{tabular}

${ }^{*}$ Complete citations are given in the Reference section 


\section{Figure 1}

US Patent Classes with Software/Business Method Patents

Granted 1976-2006

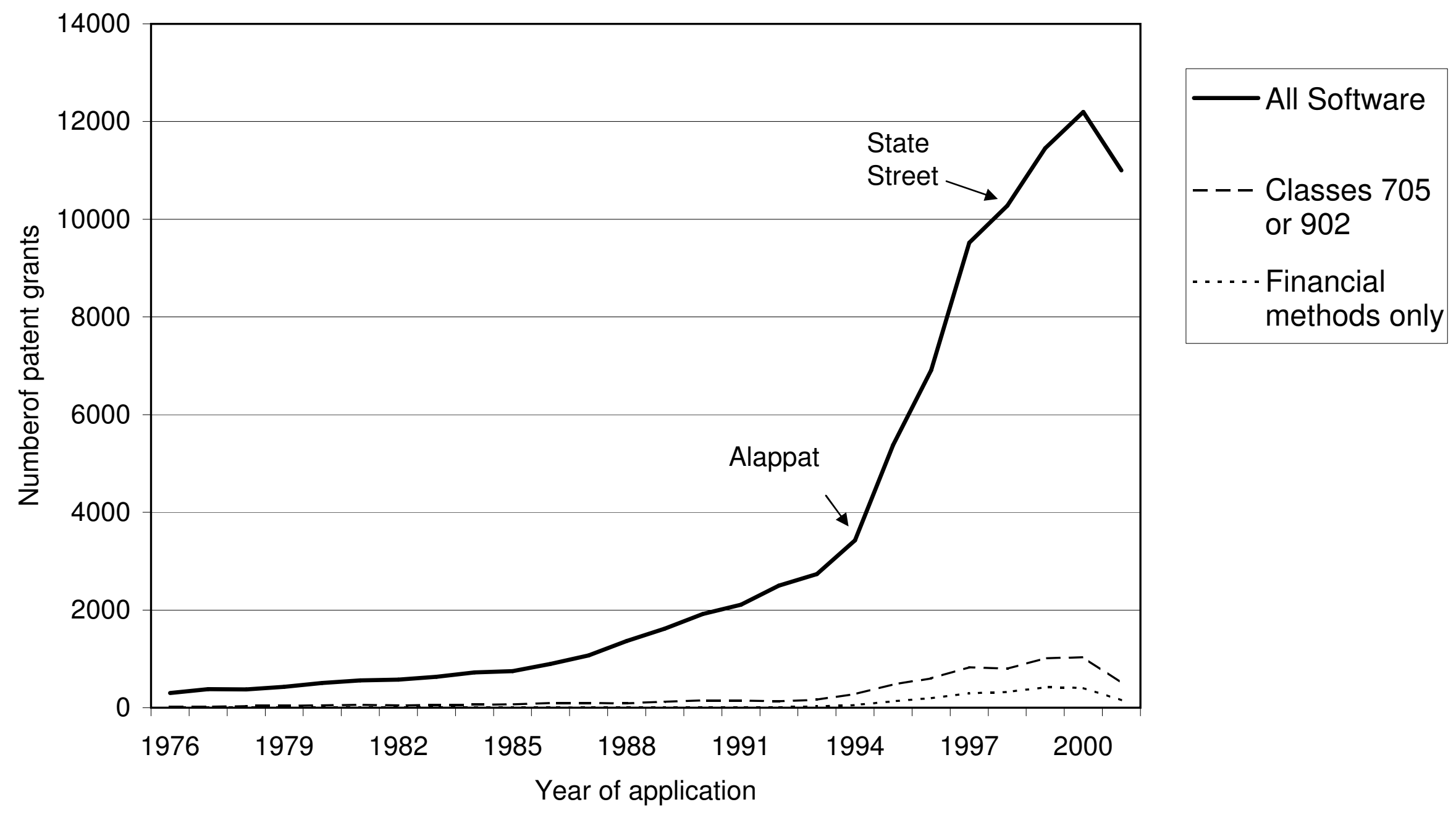


Figure 2

US Patent Classes with Software/Business Method Patents

Granted 1976-2006

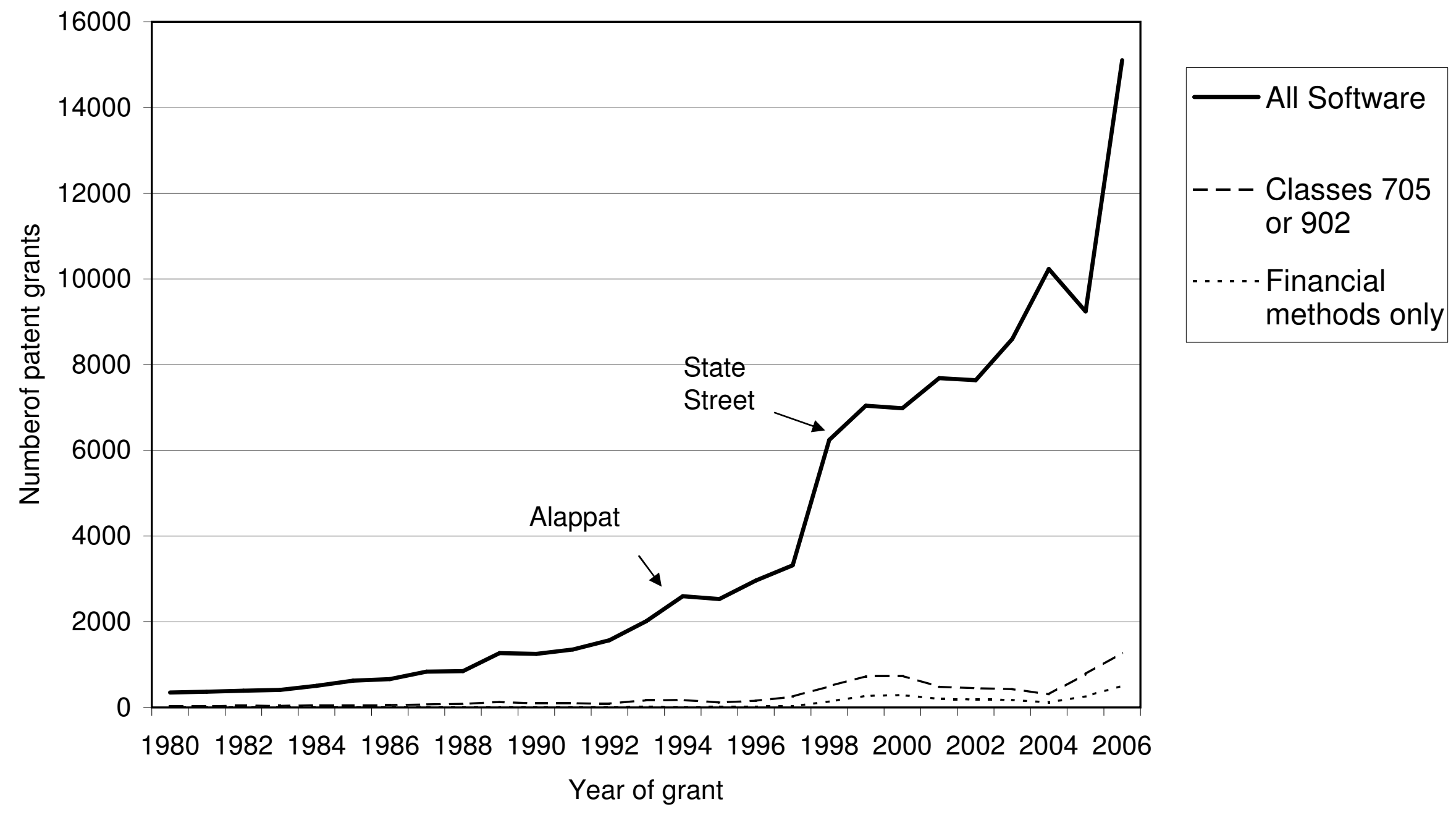




\section{Figure 3}

Business and Financial Method Patents granted by 2006

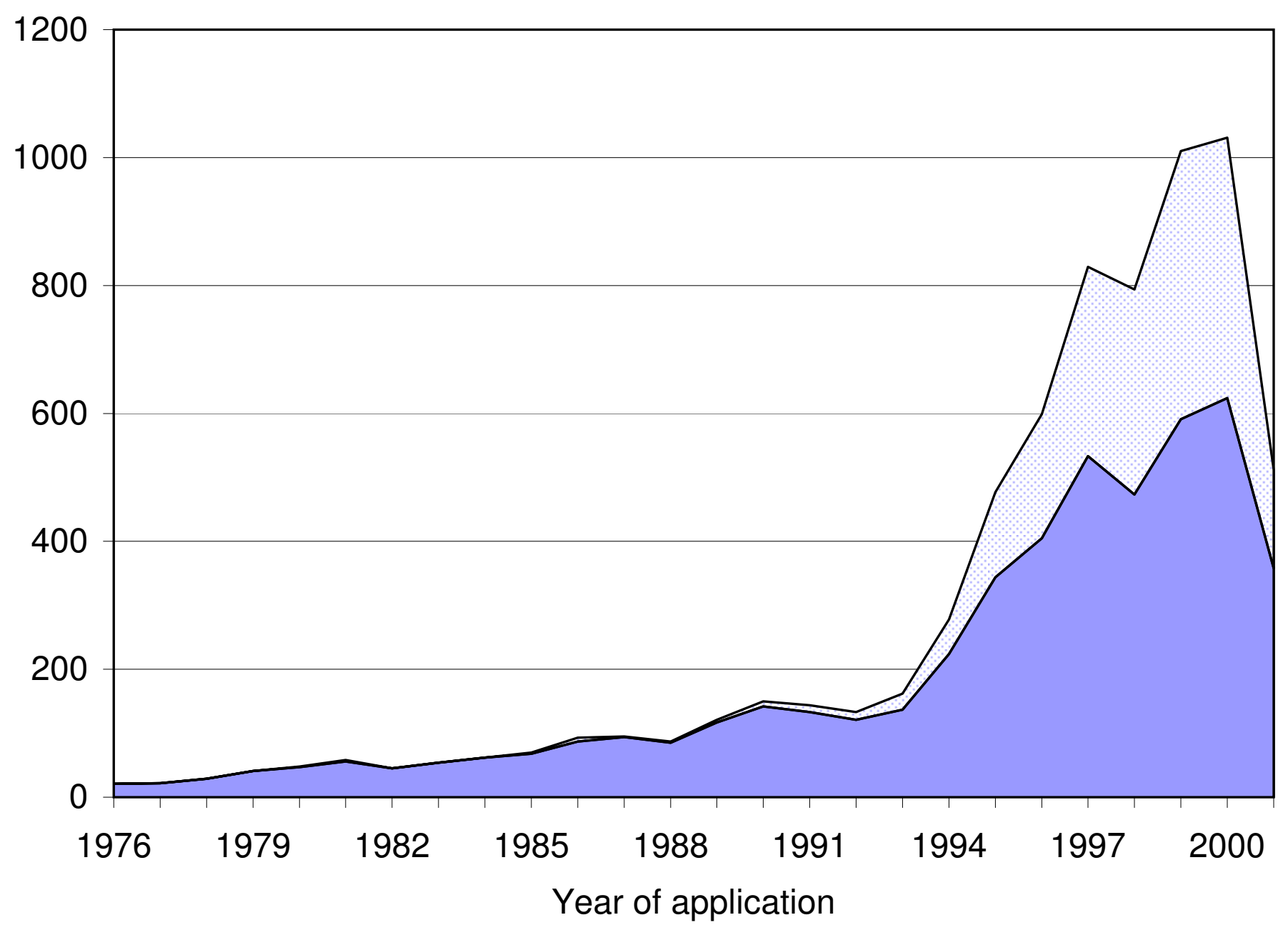

